\title{
Impact of Child Development Psychology on Conflicts Between Gunung Jaya and Sampoabalo Village, Buton of Regency
}

\author{
M Ulfa ${ }^{*}$, R S Sadif ${ }^{1}$, W O Husniah ${ }^{1}$, Unhaluddin K${ }^{1}$, L M H Adan²,
}

M A Isra Miranti Aim ${ }^{3}$

\author{
${ }^{1}$ Department of Guidance and Counseling, Faculty of Teacher Training and Education, Universitas Muhammadiyah \\ Buton, Baubau, Indonesia \\ ${ }^{2}$ Departement of Accounting, Faculty of economy, Universitas Muhammadiyah Buton, Baubau, Indonesia \\ ${ }^{3}$ Student in Department of Guidance and Counseling, Faculty of Teacher Training and Education, Universitas \\ Muhammadiyah Buton, Baubau, Indonesia \\ *Corresponding author. Email: ulfa.razak88@gmail.com
}

\begin{abstract}
The environment is one of the factors that influence the establishment of individual behavior. This study aims to determine and describe the psychological impact of children's development on conflict areas. This study uses a phenomenological approach with qualitative descriptive methods. The research sites are in two villages, Sampoabalo and Gunung Jaya, Siontapina District, Buton of Regency. Data collection using triangulation techniques. From the results of this study it can be concluded that the conflict between the villages of Gunung Jaya and Sampoabalo is very bad, not only felt by children, but also affects adolescents, adults and the elderly. Impact of this conflict deeply traumatized the trauma of all residents in the two villages. If there is no sustained trauma recovery assistance, it will create feelings of resentment, both for children and adults who have not been treated.
\end{abstract}

Keywords: psychological, child, conflicts, Buton

\section{INTRODUCTION}

The environment is one of the factors that influence the establishment of individual behaviour, it is related of development children psychological. World Health Organization explains that children born and living in areas prone to disasters, whether natural disasters, war or armed conflict are at high risk of failure in growth and developmental delays [1]. Delay in growth and development is a serious problem for both developed and developing countries in the world [2].

Late psychological development will affect the growth and development of children, both physically and mentally. Which showed that the conflict in Thailand caused growth disturbance with a prevalence of underweight $19.3 \%$, Stunting $27.6 \%$ and wasting $7.4 \%$ and developmental delays including the ability to coarse, smooth motion, language and talk and socialization and independence $31.1 \%$ [3].

Child development psychology covers various aspects. States the development of early childhood includes cognitive, physical, social, and emotional development [4]. Agree with that, in this study, aspects in the development of children's psychology in general, including physical, cognitive and psychosocial aspects. Researchers in this case combine social and emotional aspects into psychosocial aspects. Physical aspects related to physical growth such as body and brain, sensory capacity, motor skills and health. Cognitive aspects of studying attention, memory, problem solving, memory, thought processes, perception and language. And psychosocial aspects include the development of emotions, personality / morals and social relations.

Social conflict is generally interpreted as a social phenomenon that is often present in people's social lives. Conflicts in social life due to conflict of interest, desire for opinions, etc. that at least involve two or more matters [5]. Conflict is also a social phenomenon that involves disputes between parties. Parties involved in the conflict can take the form of individuals, groups, organizations, countries or nations [6]. Many factors cause conflict in society including cultural differences, differences in interests, and social change [7]. Conflicts can also occur due to differences between community members, differences in social status, differences between individuals. Conflict causes lack of stimulation provided by both parents and family [2] Conflicts or riots between residents that occurred in Gunung Jaya and Sampoabalo villages, Siantopina Sub-district, Buton District, led to the burning of 87 houses in Gunung Jaya village. After the burning of dozens of houses, it has a negative impact on psychological development, especially for children in the village of Gunung Jaya. This study examines, "What is the psychological impact of child development on conflict in the villages of Gunung Jaya and Sampoabalo?" 
The purpose of this research is to find out and describe the impact of child development psychological on conflict in the villages of Gunung Jaya and Sampoabalo, Siantopina District, Buton Regency.

\section{METHOD RESEARCH}

This research uses descriptive qualitative research methods. This research is expected to be able to explain the impact of children's psychological development from the conflict between the two villages of Gunung Jaya and Sampoabalo, Siantopina District, Buton Regency. The subjects in this study were Gunung Jaya villagers aged 3-5 years old, experienced or witnessed the conflict, and were willing to become informants. Sources of data used are children who experience or feel conflicts that occur. The type of data used is primary data that is data obtained directly from the field with direct interviews with children and parents and families who experience and feel conflict, and secondary data in the form of literature or documents from internet, journals, print and electronic media. The data collection techniques used with triangulation techniques are data collection techniques that combine various data collection techniques and existing sources [8], in this case the researcher uses participatory observation, in-depth interviews, and documentation for data sources simultaneously.

\section{RESULTS AND DISCUSSION}

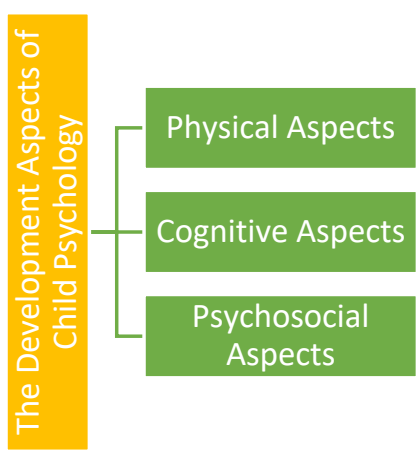

Figure 1 Aspects Of The Child's Psychological Development

The results of research conducted in the village of Gunung Jaya involving children aged 3-5 years, related to aspects of the development of children's psychology (Figure 1) is that the physical condition of the child is very alarming, seen from clothing, body, and health that is very declining. Postconflict children still use dirty clothes that have been worn for days, body that is not neglected, declining health such as influenza, fever, burns left alone. In the cognitive aspect, children need more attention, in addition to the negative perceptions of Gunung Jaya village children towards Sampoabalo village children and vice versa. When researchers interact, children are more silent, the creative process of children decreases, it appears when children are invited to play. Psychosocial aspects that occur are children are more sensitive means children are more easily upset when called one of the names of villages both Gunung Jaya and Sampoabalo villages, children's personalities are more closed and some children aged 3-5 years withdraw, and are reluctant to join the group play it.

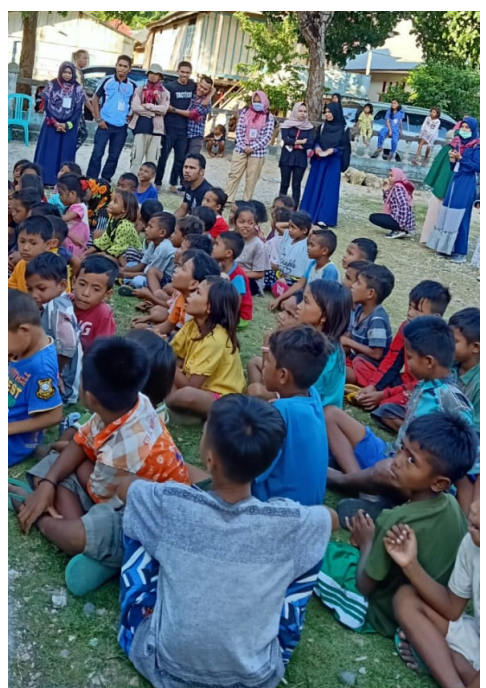

Figure 2 Condition of Sampoabalo Village Children After Conflict Between Villages

Based on the description above, conflicts/clashes that occur between the villages of Gunung Jaya and Sampoabalo are very bad for the psychological development of children. The conflict not only has an impact on the psychological development of children, but also has an impact on government activities, economic conditions, health, safety, and education that actually have an impact on all aspects of local environmental life. One month after the conflict, children and adolescents are still not allowed to go to school, there are no office activities, food and clothing are only sourced from community and government assistance, security is still heavily guarded by members of the military and police, and there is still a lack of medical personnel in paying attention to health children, adolescents and the elderly.

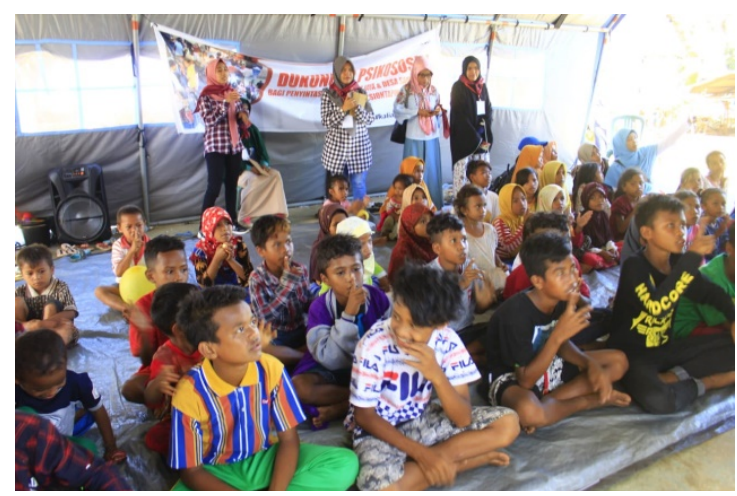

Figure 3 Child Psychosocial Assistance in the Village of Gunung Jaya

Post-conflict between the two villages caused trauma especially for children. Trauma to victims of violent conflict 
or clashes cannot be left alone. Some conditions that could potentially be traumatic events include disasters, becoming a criminal victim, losing a loved one, losing property [9]. That the event/state of fear (trauma) that is not controlled when the threat / disaster occurs until the threat has passed (disappeared), in this case the so-called general symptoms of Post-Traumatic Stress Disorder (PTSD) [10]. Not only knowing the psychological effects of child development after conflict, but researchers are trying to treat children with trauma healing. Conflict victims must be able to live normally as before and needed assistance for recovery of trauma (trauma healing). Trauma healing is a method to reduce and treat trauma to victims of natural disasters or conflict.

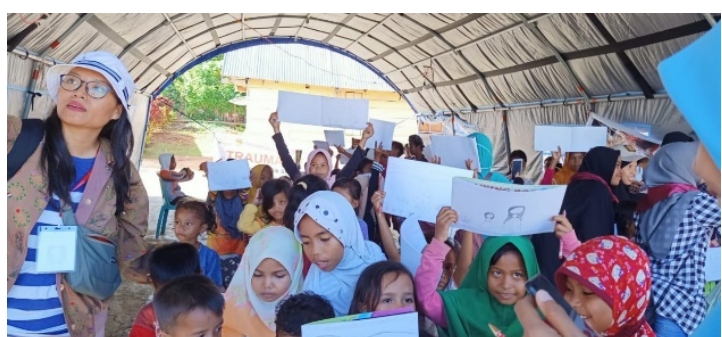

Figure 4 Trauma Healing Process the Children of Sampoabalo Village

In principle, the use of trauma healing in adults is different from trauma healing in children. In children, trauma healing is done by several methods such as play therapy using media games and expressing emotions through dance and pictures [11]. In the process of trauma healing to victims of conflict between the villages of Gunung Jaya and Sampoabalo (figure 4), researchers invited children to play outdoors. Some games like, singing while clapping. This is done to attract attention and get to know one another and establish emotional closeness. After that, the researchers again invited the children to play in the room in this case is playing in a refugee tent. In the tent, the researcher invites children to play through stories, guessing through learning media that have been prepared and drawing. Some children are asked to draw things that have been seen or felt, there are also children who do not want to follow and do activities.

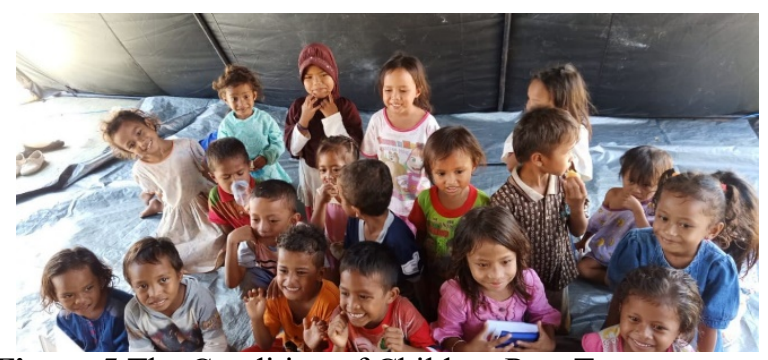

Figure 5 The Condition of Children Post Trauma Healing Children of Gunung Jaya

After doing trauma healing to children in Gunung Jaya village (figure 5), it seems that children are more cheerful than before, starting to open up to communicate, which was difficult to smile can give a happy smile and laugh, and social relationships between children begin to know each other and look after. Based on the description above, it can be seen the adverse effects of conflicts between the villages of Sampoabalo and Gunung Jaya. These adverse effects are not only felt by children but also felt by adolescents, adults and the elderly. The effects of this conflict deeply traumatized each resident in the two villages. This trauma, will most likely also cause feelings of revenge both for children and adults who have not been treated with a sense of trauma. Although trauma healing is not yet able to treat the trauma victims of the conflict, but with trauma healing therapy that is done can reduce the trauma to children victims of conflict and other disasters.

\section{CONCLUSION}

Conflicts between the villages of Gunung Jaya and Sampoabalo have a negative impact, not only felt by children but also felt by teenagers, adults and the elderly. The effects of this conflict deeply traumatized each resident in the two villages. This trauma, will most likely also cause feelings of revenge both for children and adults who have not been treated with a sense of trauma.

\section{REFERENCES}

[1] Word Health Organization, "Making a difference: Indicators to improve chidren's environmental health," in Indikator Perbaikan Kesehatan Lingkungan Anak, Aprianingsih; Erita Agustin Hardianti, Ed. Jakarta: EGC, 2009, p. 87.

[2] H. Usman, H. Sukandar, and M. Sutisna, "Pertumbuhan dan Perkembangan Anak Usia 3-24 Bulan di Daerah Konflik," Kesmas Natl. Public Heal. J., 2014.

[3] R. Jeharsae, R. Sangthong, W. Wichaidit, and V. Chongsuvivatwong, "Growth and development of children aged 1-5 years in low-intensity armed conflict areas in Southern Thailand: A community-based survey," Confl. Health, 2013.

[4] F. Stephanie, M. Eva, and N. Sherry, Who Am I in the Lives of Children? an Introduction to Early Childhood Education. Pearson Education, Incorporated, 2018, 2018.

[5] Elly M. Setiadi \& Usman Kolip, Pengantar Sosiologi Politik. Jakarta: Kencana, 2013.

[6] "Encyclopedia of educational psychology," Choice Rev. Online, 2008.

[7] M. Wieviorka, "Social conflict," Curr. Sociol., 2013.

[8] Sugiyono, "Metode Penelitian Kuantitatif, Kualitatif dan R \& D". Bandung: Alfabeta. 
[9] D. Gillies, F. Taylor, C. Gray, L. O’Brien, and N. D'Abrew, "Psychological therapies for the treatment of post-traumatic stress disorder in children and adolescents (Review)," Evidence-Based Child Health. 2013.

[10] J. D. Kinzie, "Post-Traumatic Stress Disorder," in International Encyclopedia of the Social \& Behavioral Sciences: Second Edition, 2015.

[11] A. Rahman, “Analisa Kebutuhan Program Trauma Healing Untuk Anak-anak Pasca Bencana Banjir di Kecamatan Sungai Pua Tahun 2018 : Implementasi Manajemen Bencana,” J. Menara Ilmu, 2018. 